\title{
On capillary analysis: A method of separating and recognizing individual colouring-matters in their mixtures
}

\section{F. Goppelsroder}

To cite this article: F. Goppelsroder (1888) On capillary analysis: A method of separating and recognizing individual colouring-matters in their mixtures, Philosophical Magazine Series 5, 25:154, 244-244, DOI: $10.1080 / 14786448808628178$

To link to this article: http://dx.doi.org/10.1080/14786448808628178

冓 Published online: 29 Apr 2009.

Submit your article to this journal $₫$

Џll Article views: 2

Q View related articles $\sqsubset$ 


\section{ON CAPILLARY ANALYSIS : A METHOD OF SEPARATING AND RECOGNIZING INDIVIDUAL COLOURING-MATTERS IN THEIR MIXTURES. BY F. GOPPELSRODER.}

The properties and reactions of the pure colouring-matters are accurately studied, and therefore the nature of a particular colouring-matter may be pretty readily ascertained. But the separation of the constituents of colouring-matters is in general a very difficult problem. The new method of capillary analysis renders it possible in many cases to form in a short time a judgment as to the composition of even very complicated substances. The basis of the method is very simple, and is already contained in the researches of Schönbein. If a strip of white unglazed paper is placed in any given solution, the solvent rises more or less rapidly than the dissolved body. Different dissolved substances have different rates of travelling.

If the bottom-end of a strip of pure filtering paper is dipped in a not too concentrated solution of the mixture to be investigated, according to circumstances in from 15 minutes to 12 hours, a series of zones of different colours are obtained, which contain the individual colouring-matters. The separate zones are noted as to their colour and breadth, and are then treated with suitable solvents. With the extracts thus produced fresh capillary experiments are made, and the entire operation is repeated until zones of the individual pure colouring-matters are obtained, which can be examined according to the ordinary reaction-methods.

The new method has done the author good service in examining food, and various other articles as to the addition of colours; for instance, of picric acid in beer, fuchsine in wine \&c.-Beiblätter der Physik, vol. xi. p. 754 (from Romen's Journal, No. 1, 1887).

\section{ON THE CONVECTION OF ELECTRICITY BY EVAPORATION. BY DR. ERNST LECHER.}

The author first of all shows, by thermometric means, that an electrified liquid eraporates more rapidly than an unelectrified one under the same circumstances. It cannot, however, be concluded that this is a consequence of the electrification of vapour; it is primarily and almost exclusively a consequence of the electrical aura, which also renders impossible any decision as to the far more subtle question of the magnitude of the heat of evaporation of an electrified liquid.

It is moreover prored by a simple arrangement of the experiment that, by strong electrification of a liquid surface, an electrified cloud (or a cloud of electritied drops) may be formed; that is, its inductive action can be demonstrated.-Sitzungsberichte der kaiserlichen Akademie in Wien, June 1887. 